\title{
Rubrics use and in-class feedback in higher education: Students' perceptions and their effect on academic achievement
}

\author{
Bono, Roser $^{a, b}$; Núñez-Peña, María Isabel ${ }^{a, b}$ and Suárez-Pellicioni, Macarena ${ }^{c}$ \\ ${ }^{a}$ Department of Social Psychology and Quantitative Psychology, University of Barcelona, \\ Spain, ${ }^{\mathrm{b}}$ Institute for Brain, Cognition and Behavior, University of Barcelona, Spain \\ ${ }^{\mathrm{c}}$ Department of Communication Sciences and Disorders, University of Texas at Austin.
}

\begin{abstract}
This study examines students' views regarding two types of feedback: that obtained through rubrics and that given by the class tutor (rubrics and inclass feedback, respectively). We constructed an ad hoc questionnaire to assess students' perceived usefulness of both types of feedback. The sample comprised 135 undergraduates from the University of Barcelona who were enrolled in a Research Designs course as part of the degree in Psychology. On almost all the questionnaire items the percentage of positive views was high for both types of feedback, although especially for in-class feedback. As for academic achievement, we observed no statistically significant differences between those students who only used rubrics, those who attended feedback classes and those who received both types of feedback. However, the latter left fewer questions unanswered in the multiple-choice exam, as compared with their peers who only used rubrics. Finally, those students who felt that the use of rubrics and feedback classes had helped them feel less anxious about exams obtained higher grades.
\end{abstract}

Keywords: rubrics; in-class feedback; academic achievement; higher education. 


\section{Introduction}

Recent research has highlighted the importance of feedback for improving learning (Hodgson \& Pang, 2012; Núñez-Peña et al., 2015; Panadero \& Jonsson, 2013). There are two ways in which students can receive feedback: through rubrics and directly from the tutor in class. Studies have suggested that in-class feedback provided by tutors can help students to develop their learning (Hattie, 2013; Panadero \& Romero, 2014). However, a recent study by Sáiz and Bol (2014) showed that the use of rubrics is equally as efficient.

Rubrics are an assessment tool that provides feedback regarding students' performance of tasks (Jonsson \& Svingby, 2007). Research has concluded that approaches to instruction which help students to develop their self-assessment skills can facilitate learning (Efklides, 2012; Hodgson \& Pang, 2012; Panadero et al., 2012; Sáiz et al., 2012). A further advantage of rubrics is that they can help students to monitor and assess their progress in a task both during its execution and upon completing it (Panadero \& Jonsson, 2013). The frequent use of tasks that can be assessed by rubrics, coupled with detailed feedback from tutors is therefore key to high-quality learning. Indeed, it has been shown that continuous assessment with error feedback increases its benefits, especially when rubrics are available (Morales, 2009).

In light of these previous findings, we were interested in determining which kind of feedback would be more useful for improving students' learning: rubrics or personalized inclass feedback. To this end, we first examined students' perceptions regarding the utility of the feedback given in class and that received through rubrics. We then studied the influence that both types of feedback have on academic achievement.

\section{Methods}

\subsection{Participants}

Participants were 135 undergraduates from the University of Barcelona who were enrolled during the 2015-2016 academic year in a Research Designs course as part of a degree in Psychology. The sample comprised 99 women (73.3\%) and 36 men $(26.7 \%)$ with a mean age of 21.9 years (standard deviation 5.1, range 18-50). 


\subsection{Materials}

Rubrics were used for each practical exercise in the Research Designs course. These rubrics were developed through consensus among all course tutors. During the 2014-2015 academic year all the rubrics used were validated in a sample of 36 students. Percentages of agreement between students' self-assessments, assessment by peers and tutor assessments was above $66 \%$.

At the end of the course, participants were asked to complete a questionnaire designed ad hoc to assess the perceived usefulness of both types of feedback (Table 1).

Table 1. Questionnaire items regarding the perceived usefulness of rubrics and in-class feedback.

\begin{tabular}{|c|c|}
\hline Items about rubrics & Items about in-class feedback \\
\hline $\begin{array}{l}\text { Item } 1 \text {. The rubrics helped me to prepare for the } \\
\text { course. }\end{array}$ & $\begin{array}{l}\text { Item 9. The feedback classes helped me to } \\
\text { prepare for the course. }\end{array}$ \\
\hline $\begin{array}{l}\text { Item } 2 \text {. My learning improved as a result of the } \\
\text { rubrics. }\end{array}$ & $\begin{array}{l}\text { Item 10. My learning improved as a result of the } \\
\text { feedback classes. }\end{array}$ \\
\hline $\begin{array}{l}\text { Item 3. The rubrics gave me a better } \\
\text { understanding of the assessment criteria. }\end{array}$ & $\begin{array}{l}\text { Item 11. The feedback classes gave me a better } \\
\text { understanding of the assessment criteria. }\end{array}$ \\
\hline $\begin{array}{l}\text { Item } 4 \text {. Through the use of the rubrics I learned } \\
\text { to self-assess my performance. }\end{array}$ & $\begin{array}{l}\text { Item } 12 \text {. Through the feedback classes I learned } \\
\text { to self-assess my performance. }\end{array}$ \\
\hline $\begin{array}{l}\text { Item } 5 \text {. The rubrics helped me to feel less } \\
\text { anxious when preparing for the exam involving } \\
\text { open questions. }\end{array}$ & $\begin{array}{l}\text { Item 13. The feedback classes helped me to feel } \\
\text { less anxious when preparing for the exam } \\
\text { involving open questions. }\end{array}$ \\
\hline $\begin{array}{l}\text { Item } 6 \text {. The rubrics helped me to feel less } \\
\text { anxious when preparing for the multiple-choice } \\
\text { exam. }\end{array}$ & $\begin{array}{l}\text { Item 14. The feedback classes helped me to feel } \\
\text { less anxious when preparing for the multiple- } \\
\text { choice exam. }\end{array}$ \\
\hline $\begin{array}{l}\text { Item } 7 \text {. Overall, I think the rubrics were really } \\
\text { useful. }\end{array}$ & $\begin{array}{l}\text { Item } 15 \text {. Overall, I think the feedback classes } \\
\text { were really useful. }\end{array}$ \\
\hline $\begin{array}{l}\text { Item } 8 \text {. I would like it if there were rubrics for } \\
\text { the practical and project work of all the other } \\
\text { courses on my degree. }\end{array}$ & $\begin{array}{l}\text { Item 16. I would like it if there were feedback } \\
\text { classes for the practical and project work of all } \\
\text { the other courses on my degree. }\end{array}$ \\
\hline
\end{tabular}




\subsection{Procedure}

At the beginning of the course the rubrics were uploaded to the course website. During the course, the tutor provided specific feedback following each practical class. Prior to the end of the course, those students who had used the rubrics and/or attended the feedback classes were asked to complete the questionnaire. At the end of the course, all students sat two exams: one involving open questions and another in the form of a multiple-choice test in which the correct answer had to be chosen from among four alternatives. In order to discourage random guessing in the multiple-choice exam, students were told that incorrect answers would carry a penalty of 0.25 marks.

\section{Results}

Tables 2 and 3 show that for both types of feedback a high percentage of students perceived it to have been useful, although this was especially the case for in-class feedback.

Table 2. Percentages of responses given to each questionnaire item about the perceived usefulness of rubrics.

\begin{tabular}{rrrrrr}
\hline Items & $\begin{array}{c}\text { Strongly } \\
\text { disagree }\end{array}$ & Disagree & $\begin{array}{r}\text { Neither } \\
\text { agree nor } \\
\text { disagree }\end{array}$ & Agree & $\begin{array}{r}\text { Strongly } \\
\text { agree }\end{array}$ \\
\hline Item 1 & $0.9 \%$ & $7.5 \%$ & $33.0 \%$ & $45.4 \%$ & $13.2 \%$ \\
Item 2 & $0.9 \%$ & $12.3 \%$ & $36.8 \%$ & $42.5 \%$ & $7.5 \%$ \\
Item 3 & $1.9 \%$ & $1.9 \%$ & $7.5 \%$ & $51.9 \%$ & $36.8 \%$ \\
Item 4 & $3.8 \%$ & $6.6 \%$ & $21.7 \%$ & $52.8 \%$ & $15.1 \%$ \\
Item 5 & $10.4 \%$ & $24.5 \%$ & $33.0 \%$ & $27.4 \%$ & $4.7 \%$ \\
Item 6 & $7.4 \%$ & $20.8 \%$ & $32.1 \%$ & $34.0 \%$ & $5.7 \%$ \\
Item 7 & $0.9 \%$ & $7.5 \%$ & $24.5 \%$ & $51.1 \%$ & $16.0 \%$ \\
Item 8 & $2.8 \%$ & $1.9 \%$ & $17.9 \%$ & $34.0 \%$ & $43.4 \%$ \\
\hline
\end{tabular}


Table 3. Percentages of responses given to each questionnaire item about the perceived usefulness of in-class feedback.

\begin{tabular}{crrrrr}
\hline Items & $\begin{array}{c}\text { Strongly } \\
\text { disagree }\end{array}$ & Disagree & $\begin{array}{r}\text { Neither } \\
\text { agree nor } \\
\text { disagree }\end{array}$ & Agree & $\begin{array}{r}\text { Strongly } \\
\text { agree }\end{array}$ \\
\hline Item 9 & $0.0 \%$ & $2.3 \%$ & $12.4 \%$ & $48.9 \%$ & $36.4 \%$ \\
Item 10 & $0.0 \%$ & $2.3 \%$ & $17.8 \%$ & $45.0 \%$ & $34.9 \%$ \\
Item 11 & $0.7 \%$ & $3.9 \%$ & $13.2 \%$ & $43.4 \%$ & $38.8 \%$ \\
Item 12 & $0.0 \%$ & $4.6 \%$ & $21.7 \%$ & $41.9 \%$ & $31.8 \%$ \\
Item 13 & $4.6 \%$ & $21.7 \%$ & $29.5 \%$ & $27.1 \%$ & $17.1 \%$ \\
Item 14 & $6.1 \%$ & $18.6 \%$ & $26.4 \%$ & $35.7 \%$ & $13.2 \%$ \\
Item 15 & $0.0 \%$ & $2.2 \%$ & $17.1 \%$ & $48.1 \%$ & $32.6 \%$ \\
Item 16 & $0.7 \%$ & $0.8 \%$ & $10.9 \%$ & $41.1 \%$ & $46.5 \%$ \\
\hline
\end{tabular}

We applied the Wilcoxon signed-rank test for related samples to the responses of those students who had both used rubrics and attended feedback classes (Table 4). This analysis showed that in-class feedback was viewed more positively than were rubrics for all the analysed aspects $(p<.02)$, with the exception of the item about knowledge of assessment criteria $(p=.833)$.

Table 4. Wilcoxon signed-rank test for related samples.

\begin{tabular}{|c|c|c|c|c|c|}
\hline \multirow[b]{2}{*}{ Differences } & \multicolumn{3}{|c|}{$N$ of ranks } & \multirow[b]{2}{*}{$Z$} & \multirow[b]{2}{*}{$p$} \\
\hline & + & - & $=$ & & \\
\hline Item 9 - Item 1 & 55 & 12 & 33 & 5.309 & $<.001$ \\
\hline Item 10 - Item 2 & 59 & 12 & 29 & 5.955 & $<.001$ \\
\hline Item 11 - Item 3 & 31 & 28 & 41 & 0.211 & .833 \\
\hline Item 12 - Item 4 & 41 & 19 & 40 & 2.991 & .003 \\
\hline Item 13 - Item 5 & 40 & 13 & 47 & 3.671 & $<.001$ \\
\hline Item 14 - Item 6 & 32 & 15 & 53 & 2.342 & .019 \\
\hline Item 15 - Item 7 & 43 & 15 & 42 & 3.933 & $<.001$ \\
\hline Item 16 - Item 8 & 32 & 16 & 52 & 2.591 & .010 \\
\hline
\end{tabular}

Tables 5 and 6 show a positive correlation between a reduction in perceived test anxiety and the grades obtained, both with the use of rubrics (items 5 and 6) and with feedback classes (item 13 and 14). This significant correlation applies to both the open-answer and 
multiple-choice exams. The negative correlation between the reduction in perceived test anxiety and the number of questions left unanswered in the multiple-choice exam was also significant. Moreover, for those students who used rubrics, a negative correlation was observed between the reduction in perceived test anxiety and the number of errors in the multiple-choice exam.

Item 7, referring to students' overall view regarding the utility of rubrics, was positively correlated with the grades obtained in the open-answer exam and negatively correlated with the number of questions left unanswered in the multiple-choice exam. Items 10 and 11, referring to students' views on whether feedback classes improved their learning and their understanding of assessment criteria, were positively correlated with performance in the open-answer exam. Item 12, referring to whether feedback classes helped students to selfassess, was positively correlated with the grades obtained in both types of exams, as well as with the number of correct answers in the multiple-choice exam. The correlation between item 12 and the number of errors made in the multiple-choice exam was negative. Finally, a significant correlation was observed between the need to include in-class feedback in other courses of the degree (item 16) and the grades obtained in the open-answer exam.

Table 5. Correlations between performance in the Research Designs course and response to the items referring to the perceived usefulness of rubrics.

\begin{tabular}{|c|c|c|c|c|c|}
\hline \multirow{3}{*}{ Items } & \multicolumn{5}{|c|}{ Exams } \\
\hline & \multirow{2}{*}{$\begin{array}{l}\text { Open answers } \\
\text { Mark }\end{array}$} & \multicolumn{4}{|c|}{ Multiple choice } \\
\hline & & Mark & Hits & Errors & $\begin{array}{l}\text { Unanswered } \\
\text { questions }\end{array}$ \\
\hline Item 1 & .138 & .050 & .070 & -.039 & -.133 \\
\hline Item 2 & .186 & .093 & .097 & -.055 & -.075 \\
\hline Item 3 & .095 & -.067 & -.064 & .047 & .036 \\
\hline Item 4 & .157 & .118 & .126 & -.050 & -.124 \\
\hline Item 5 & $.416 * *$ & $.410 * *$ & $.414 * *$ & $-.290 * *$ & $-.278 * *$ \\
\hline Item 6 & $.351^{* *}$ & $.399 * *$ & $.404 * *$ & $-.259 * *$ & $-.295 * *$ \\
\hline Item 7 & $.206^{*}$ & .158 & .175 & -.033 & $-.209 *$ \\
\hline Item 8 & .145 & .010 & .015 & -.003 & -.021 \\
\hline
\end{tabular}


Table 6. Correlations between performance in the Research Designs course and response to the items referring to the perceived usefulness of in-class feedback.

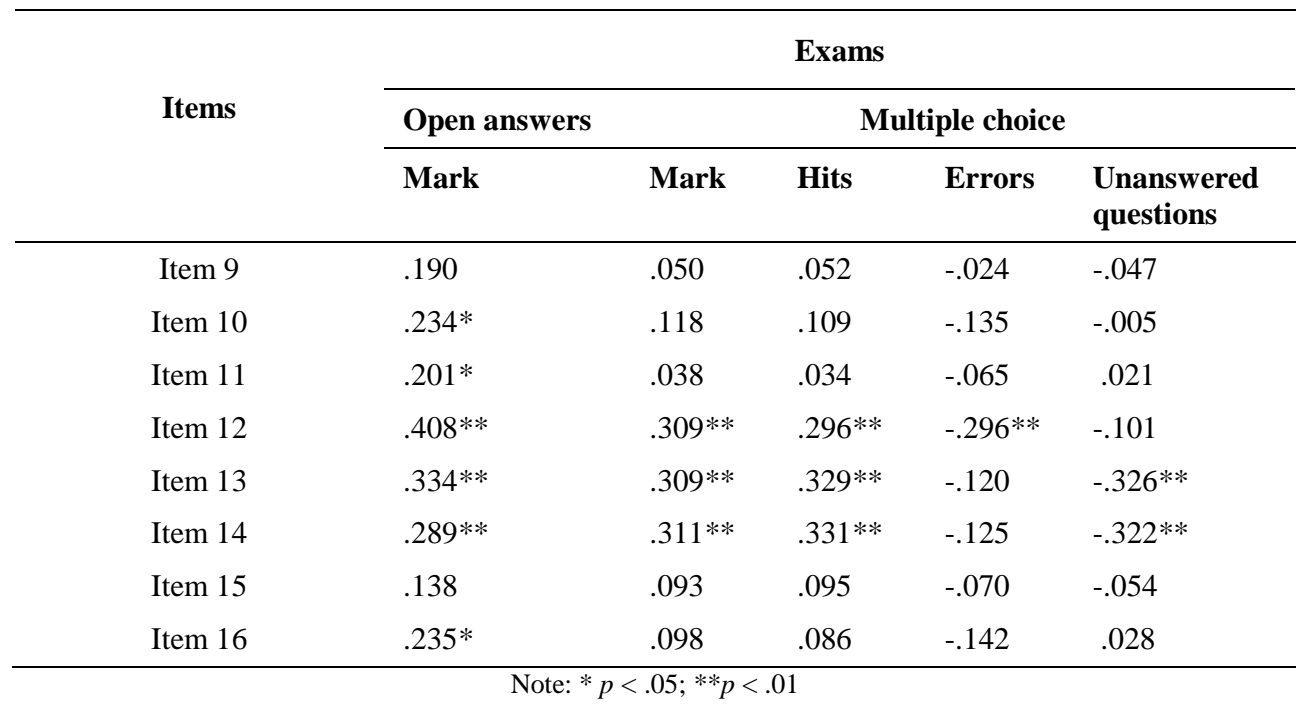

Results from analyses of variance showed no statistically significant differences in academic performance between those students who only used rubrics, those who only attended feedback classes and those who used rubrics and attended feedback classes, this being the case for both the open-answer exam $(F(2,130)=0.654, p=.522)$ and the multiple-choice exam $(F(2,128)=2.191, p=.116)$. However, results from the Bonferroni correction showed that students who benefitted from both types of feedback left fewer questions unanswered in the multiple-choice exam, as compared with those students who only used rubrics $(p=.015)$.

\section{Discussion}

Students felt that both types of feedback were useful for their learning, although of the two the most positive ratings were given to direct feedback from tutors. The analysis also showed that those students who reported feeling less anxious about exams as a result of using rubrics or attending feedback classes did better in their exams. This result is consistent with the findings of Andrade and Du (2005), Panadero et al. (2012) and Reynolds-Keefer (2010). These authors concluded that the use of rubrics helped reduce negative emotions such as anxiety, leading in turn to better performance. Finally, those students who both used rubrics and received in-class feedback left fewer questions unanswered in the multiple-choice exam, as compared with their peers who only used rubrics. This may indicate that when students receive more personalized in-class feedback, 
they feel better prepared and more capable of succeeding in exams. Thus, feedback given by the tutor might boost students' confidence regarding their knowledge of the course content. Similar results were recently obtained by Núñez-Peña et al. (2015), who found a positive relationship between academic performance and perceived usefulness of in-class feedback. These authors concluded that giving in-class feedback about errors helped students to feel more confident about their learning ability, reducing — in a course with mathematical content — the negative impact of math anxiety on performance.

In conclusion, the results of this study show that approaches to teaching which involve feedback (both rubrics and in-class feedback) may lead students to have a more favourable view of their learning, especially when the feedback is given in a more personalized way, in class. Both types of feedback were able to reduce perceived test anxiety in students and, moreover, those students who reported feeling less anxious as a result of feedback did better in their exams. This suggests that both types of feedback can help students to approach assessment without the emotional tension that is usually associated with academic achievement.

\section{References}

Andrade, H., \& Du, Y. (2005). Student perspectives on rubric-referenced assessment. Practical Assessment, Research and Evaluation, 10, 1-11.

Efklides, A. (2012). Commentary: How readily can findings from basic cognitive psychology research be applied in the classroom? Learning and Instruction, 22, 290295.

Hattie, J. (2013). Calibration and confidence: Where to next? Learning and Instruction, 24, 62-66.

Hodgson, P., \& Pang, M. Y. C. (2012). Effective formative e-assessment of student learning: A study on a statistics course. Assessment and Evaluation in Higher Education, 37, 215-225.

Jonsson, A., \& Svingby, G. (2007). The use of scoring rubrics: Reliability, validity and educational consequences. Educational Research Review, 2, 130-144.

Morales, P. (2009). Ser profesor: una mirada al alumno. Guatemala: Universidad Rafael Landívar.

Núñez-Peña, M. I., Bono, R., \& Suárez-Pellicioni, M. (2015). Feedback on students' performance: A possible way of reducing the negative effect of math anxiety in higher education. International Journal of Educational Research, 70, 80-87.

Panadero, E., Alonso-Tapia, J., \& Huertas, J. A. (2012). Rubrics and self-assessment scripts effects on self-regulation, learning and self-efficacy in secondary education. Learning and Individual Differences, 22, 806-813.

Panadero, E., \& Jonsson, A. (2013). The use of scoring rubrics for formative assessment purposes revisited: A review. Educational Research Review, 9, 129-144. 
Panadero, E., \& Romero, M. (2014). To rubric or not to rubric? The effects of selfassessment on self-regulation, performance and self-efficacy. Assessment in Education: Principles, Policy and Practice, 21, 133-148.

Reynolds-Keefer, L. (2010). Rubric-referenced assessment in teacher preparation: An opportunity to learn by using. Practical Assessment, Research and Evaluation, 15, 1-9.

Sáiz, M. C., \& Bol, A. (2014). Aprendizaje basado en la evaluación mediante rúbricas en educación superior. Suma Psicológica, 21, 28-35.

Sáiz, M. C., Montero, E., Bol, A., \& Carbonero, M. A. (2012). An analysis of learning competences at the university. Electronic Journal of Research in Educational Psychology, 10, 253-270. 